\title{
PERANCANGAN SISTEM INFORMASI PADA CV ARLET LAUNDRY BERBASIS JAVA NETBEANS DAN MYSQL
}

\author{
Aris Muhamad Haris ${ }^{1}$, Ulfa Pauziah², Zikriah \\ ${ }^{1,2,3}$ Teknik Informatika, Fakultas Teknik dan Ilmu Komputer, Universitas Indraprasta PGRI \\ Jalan Raya Tengah No 80, Kelurahan Gedong, Pasar Rebo, Jakarta Timur \\ 1harismuhamad142@gmail.com, ${ }^{2}$ ulfapauziah9@gmail.com, ${ }^{3}$ qie.zikriah80@gmail.com
}

\begin{abstract}
ABSTRAK
Sistem Informasi Pada CVArlet Laundry Berbasis Java Netbeans dan MySQL merupakan suatu sistem yang dibuat untuk membantu layanan transaksi pelangggan dimana dalam sistem informasi tersebut mengelola data pelanggan, data transaksi pelanggan.dalam hal ini CV Arlet Laundry sebagai tempat penelitian, karena sistem informasi transaksi ditempat tersebut masih belum terkelola dengan baik, sehingga seringkali terjadinya kesalahan dalam mengelola data-data, kehilangan data dan kesalahan dalam membuat laporan seperti laporan data pelanggan dan data transaksi. Tujuan dari penelitian ini untuk menyelesaiakan masalah yang ada pada CV Arlet Lundry. Metode penelitian yang digunakan yaitu penelitian Research and Development (R\&D), alat bantu analisis yang digunakan yaitu diagram konteks, data flow diagram (DFD), relasi table, dan entity relatins diagram (ERD), perangkat lunak yang digunakan yaitu Java Netbeans IDE 8.0.2 dan XAMPP Control Panel 3.2.4..dalam merancang dan melakukan evaluasi sistem yang memiliki beberapa tahapan yaitu,tahap perencanaan, analisis, desain, implementasi, uji coba sistem, dan pengelolaan. Penelitian ini menghasilkan aplikasi sistem informasi berbasis Java Netbeans dan MySQL yang mempermudah dalam pengelolaan data maupun penyajian informasi data pelanggan dan data transaksi pada CV Arlet Laundry dengan efektif dan akurat.
\end{abstract}

Kata Kunci: Sistem Informasi, Laundry, Java

\begin{abstract}
The Information System at CVArlet Laundry Based on Java Netbeans and MySQL is a system created to assist customer transaction services where the information system manages customer data and customer transaction data. In this case CV Arlet Laundry as a place of research, because the information system transactions in the se places are still not managed properly, so that there are often errors in managing data, data loss and errors in making reports such as customer data reports and transaction data. The purpose of this research is to solve the problems that exist in CV Arlet Lundry. The research method used is research Research and analytical tools used are context diagrams, data flow diagrams (DFD), relation tables, and entity relatins diagrams (ERD), the software used is Java Netbeans IDE 8.0.2 and XAMPP Control Panel 3.2.4..in designing and evaluating the system which has several stages, namely, planning, analysis, design, implementation, system testing, and management stages. This study resulted in an information system application based on Java Netbeans and MySQL that facilitates data management and presentation of customer data information and transaction data on CV Arlet Laundry effectively and accurately.
\end{abstract}

Key Word: Information Systems, Laundry, Java

\section{PENDAHULUAN}

Saat ini perkembangan teknologi terus berkembang mengikuti arah dan pergerakan zaman, kebutuhan informasi dan data-data yang akurat dan cepat sangat dibutuhkan dan penting karena untuk memudahkan dalam mengelola data-data dan informasi yang ada.

CV Arlet Laundry merupakan salah satu perusahaan yang bergerak di bidang jasa pencucian berbagai jenis pakaian yang berlokasi di bekasi dan mempunyai beberapa cabang di daerah Jakarta, Bekasi dan sekitarnya, CV Arlet Laundry masih menggunakan sistem manual dalam mengelola data seperti data pelanggan, data layanan, data transaksi dan data pengambilan pakaian. pengelolaan data-data tersebut tentunya kurang terstruktur dan efisien Karna data-data yang ada disimpan secara manual dan pembuatan bukti transaksi masih 
menggunakan kertas yang ditulis secara manual dan dalam penulisan laporan hanya menggunakan bantuan Microsoft Office Word untuk dilaporakan dan diserahkan kepada direktur.

Oleh karena itu, untuk mendukung sistem informasi pada CV Arlet Laundry yang efektif perlu dirancang suatu sistem basis data berbasis desktop yang lebih mudah digunakan karna pengolahan data bisa dilakukan secara otomatis menggunakan sistem, sehingga dapat membantu dan memudahkan dalam mengelola data-data yang dibutuhkan, Sehingga dapat lebih cepat, akurat dan efisien dalam menjalankan bisnis usahanya. Menurut (Bin Ladjamudin, 2013) menjelaskan bahwa Perancangan tahapan, memiliki tujuan untuk mendesain sistem baru yang dapat menyelesaikan masalah-masalah yang dihadapi perusahaan yang diperoleh dari pemilihan alternatif sistem yang terbaik, kegiatan yang dilakukan dalam tahap perancangan ini meliputi perancangan output, input, dan file.

Menurut (Sutabri, 2012) Sistem informasi adalah suatu sistem didalam suatu organisasi yang mempertemukan kebutuhan pengolahan transaksi harian yang mendukung fungsi operasi organisasi yang bersifat manajerial dengan kegiatan strategi dari suatu organisasi untuk dapat menyediakan kepada pihak luar tertentu dengan laporan-laporan yang diperlukan.

Menurut (Westriningsih, 2012) Netbeans merupakan salah satu IDE yang dikembangkan dengan bahasa pemrograman java. Netbeans adalah sebuah perangkat lunak open source sehingga dapat digunakan secara gratis untuk keperluan komersial maupun non komersial yang didukung oleh Sun Microsystem.

(Raharjo, 2015) mendefinisikan bahwa MySQL merupakan RDBMS (server database) yang dapat mengelola database dengan sangat cepat dan akurat, dapat menampung data dalam jumlah sangat besar, dapat diakses oleh banyak user.

Tujuan dari penelitian ini, adalah untuk merancang dan mengimplementasikan aplikasi sistem informasi, peendataan pelanggan, pendataan layanan, dan pendataan transaksi pada
CV Arlet Laundry, serta mengevaluasi aplikasi yang telah dihasilkan.

Manfaat dari Penelitian ini, yaitu untuk mengatasi masalah yang ada pada CV Arlet Laundry untuk memberikan kemudahan kepada pihak perusahaan dalam mengelola data pelanggan, data layanan, dan data transaksi.

\section{METODE PENELITIAN}

Penelitian yang digunakaan yaitu metode penelitian Research and Development (R\&D). Menurut (Sugiyono, 2016), Research and Development (R\&D) merupakan metode penelitian yang digunakan untuk menghasilkan produk tertentu dan menguji keefektifan produk tersebut. Sehingga penelitan yang dilakukan secara sengaja dan sistematis untuk menyempurnakan produk yang telah dirancang maupun mengembangkan suatu produk baru melalui pengujian, sehingga produk tersebut dapat dipertanggungjawabkan. Metode pengumpulan data yang digunakan, yaitu :

\section{Metode Lapangan}

Metode ini yang dilakukan penulis secara langsung untuk mengumpulkan data-data yang berhubungan dengan sistem transaksi pelayanan dan data cucian yang terdapat pada cv arlet laundry. Data-data tersebut penulis kumpulkan dengan cara:

\section{Observasi}

Observasi yaitu cara pengumpulan data dengan melaksanakan pengamatan langsung terhadap suatu objek dalam waktu atau periode tertentu dan melakukan pencatatan data secara sistematis hal-hal tertentu yang diamati. Penulis mempelajari dan mengamati sistem transaksi yang dilakukan pada cv arlet laundry.

\section{Wawancara}

Wawancara yaitu suatu teknik pengumpulan data yang dilakukan dengan cara tanya jawab atau interaksi antara penanya dengan narasumber. Penulis melakukan wawancara kepada Bapak Pandji Nugroho sebagai pengurus workshop cabang bekasi. 
Studi Literatur

Pengumpulan data dan informasi yang penulis lakukan untuk perancangan aplikasi sistem informasi transaksi pada cv arlet laundry, yaitu:

a. Mempelajari buku-buku literatur mengenai analisis dan desain sebuah sistem yang akan diterapkan.

b. Mempelajari sistem dari aplikasi sistem transaksi yang serupa dengan aplikasi yang akan dibuat.

c. Mempelajari buku-buku Java Netbeans dan memahami penulisan bahasa pemograman atau coding untuk mengoperasikannya dengan MySQL sebagai databasenya.

\section{Studi Pustaka}

Studi pustaka dengan mencari data-data dan informasi melalui buku-buku dan dari Internet yang berkaitan dengan penelitian.

\section{HASIL DAN PEMBAHASAN}

Bedasarkan masalah-masalah yang dihadapi berikut adalah analisis proses yang diusulkan pada sistem informasi CV Arlet Laundry yaitu :

1. Input data layanan

Pengisian data layanan dan harga sesuai paket dan kategori yang telah ditentukan.

2. Input data pelanggan

Pada saat pelanggan yang akan melalkukan pencucian baik pelanggan personal maupun corporate akan dilakukan pendataan oleh admin dan akan masuk ke data store pelanggan.

3. Input data transaksi

pada saata pelanggan sudah terdaftar dalam data pelanggaan maka admin counter akan memeriksa cucian dan mengitung beerapa jumlah yang harus lalu pelanggan akan mendapatkan nota sebagai bukti pembayaran.

4. Input data pengambilan

Pada saaat pelanggan personal akan melakukan pengambilan atau penyerahan cucian. Maka admin akan mencatat data cucian yang sudah disimpan ke datastore pengambilan.

5. Laporan

Pada proses laporan ada beberapa laporan yang akan dicetak untuk diserahkan kepada direktur.data yang akan dicetak seperti laporan data pelanggan personal dan laporan pelanggan corporate, laporan data transaksi, dan laporan data pengambilan berdasarkan database. Laporan-laporan yang dicetak akan diserahkan kepada direktur.

Penulis menggambarkan sistem yang diusulkan dalam bentuk DFD (Data Flow Diagram) "(A.S \& Shalahuddin, 2016) DFD dapat digunakan untuk mempresentasikan sebuah sistem atau perangkat lunak pada beberapa level yang lebih detail untuk merepresentasikan aliran informasi atau fungsi yang lebih detail.

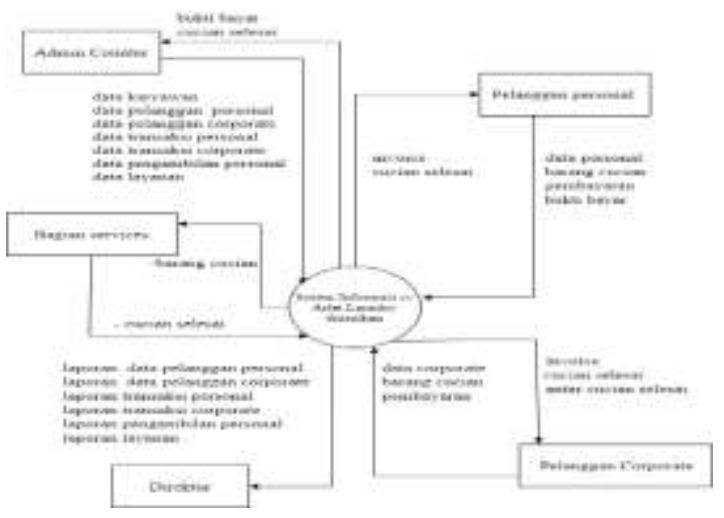

Gambar 1. Diagram Konteks Sistem Diusulkan

Hubungan antar data digambarkan dalam bentuk ERD (Entity Relationship Diagram). Menurut(A.S \& Shalahuddin, 2016) ERD (Entity Relationship Diagram) menjadi salah satu pemodelan data konseptual yang paling sering digunakan.

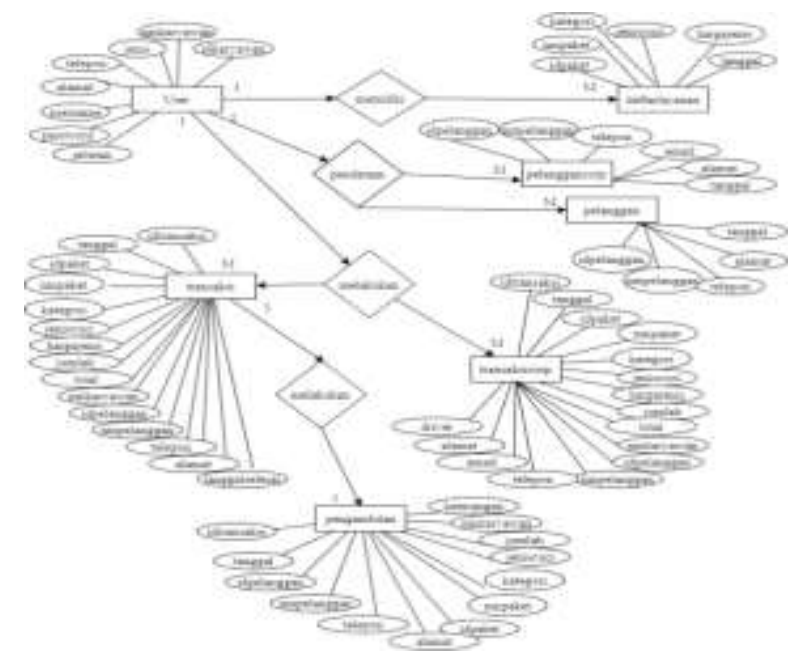

Gambar 2. ERD (Entity Relationship Diagram)

120 | Perancangan Sistem Infromasi Pada CV Arlet Laundry Berbasis Java Netbeans Dan MySQL 


\section{Tampilan Layar}

Tampilan Form Login

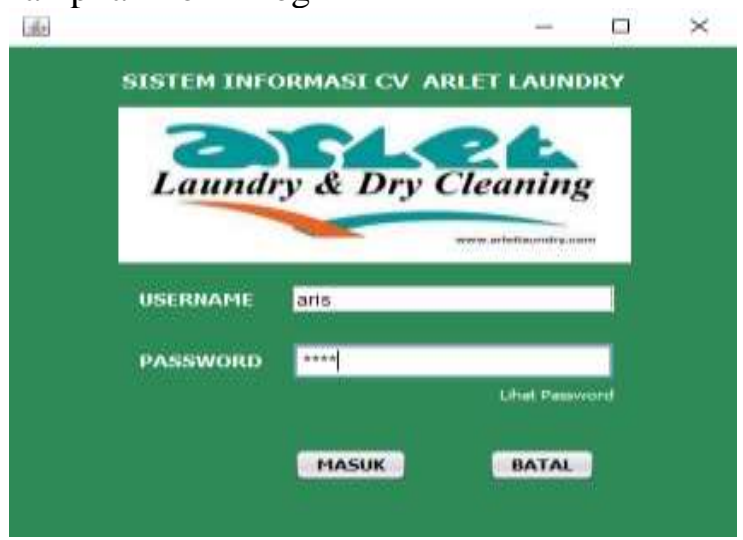

Gambar 3. Tampilan Login

Tampilan login yaitu tampilan pertama yang muncul ketika aplikasi ini dijalnkan. Dengan megisi username dan password yang sudah terdaftar di form user.

Tampilan Form Menu Utama

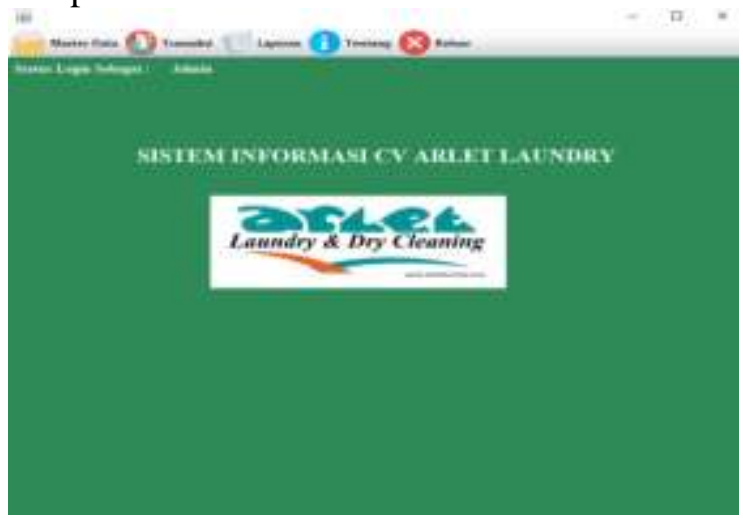

Gambar 4. Tampilan Menu Utama

Pada tampilan menu utama terdapat menu master data, transaksi, laporan, tentang dan keluar.

Tampilan Form user

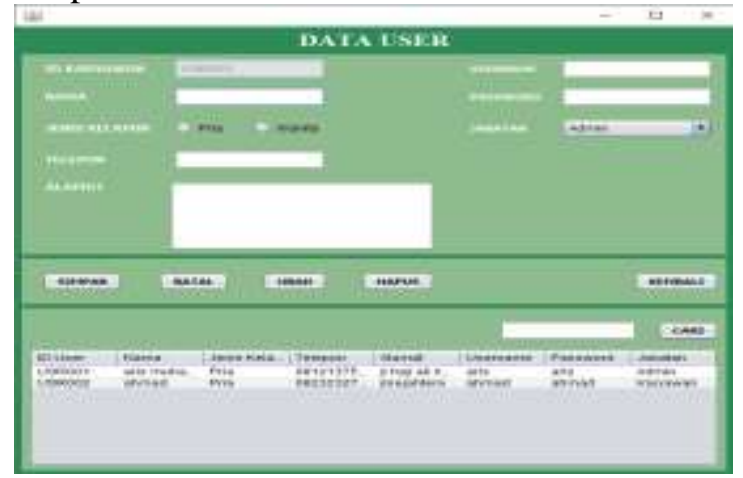

Gambar 5. Tampilan Form Data User
Form user berfungsi sebagai menyimpan data pengguna aplikasi dan sebagai akses login.

Tampilan Form Pelanggan Personal

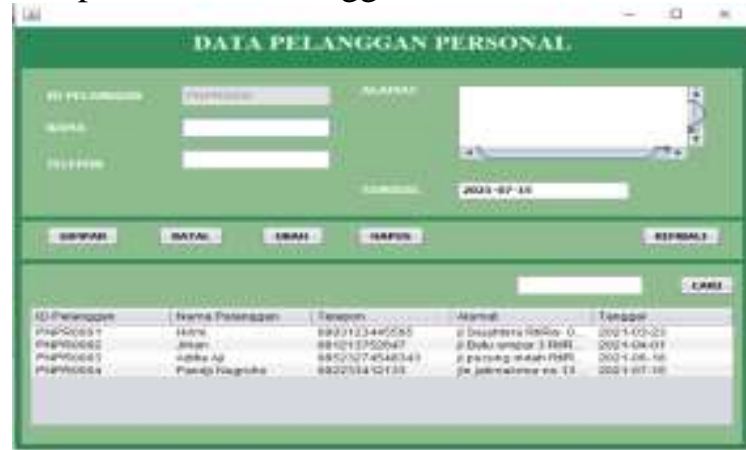

Gambar 6. Tampilan Form Data Pelanggan Personal

Form pelanggan personal berfungsi untuk meyimpan data pelanggan personal.

Tampilan Form Pelanggan Corporate

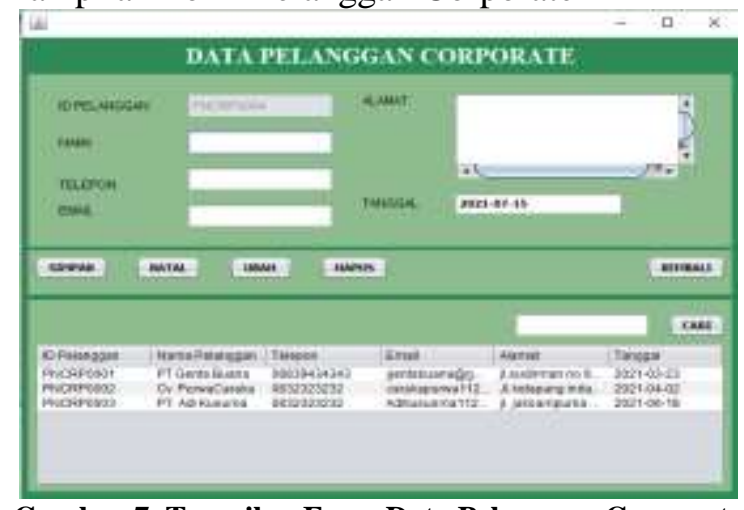

Gambar 7. Tampilan Form Data Pelanggan Corporate

Form pelanggan corporate berfungsi untuk meyimpan data pelanggan corporate.

Tampilan Form data layanan

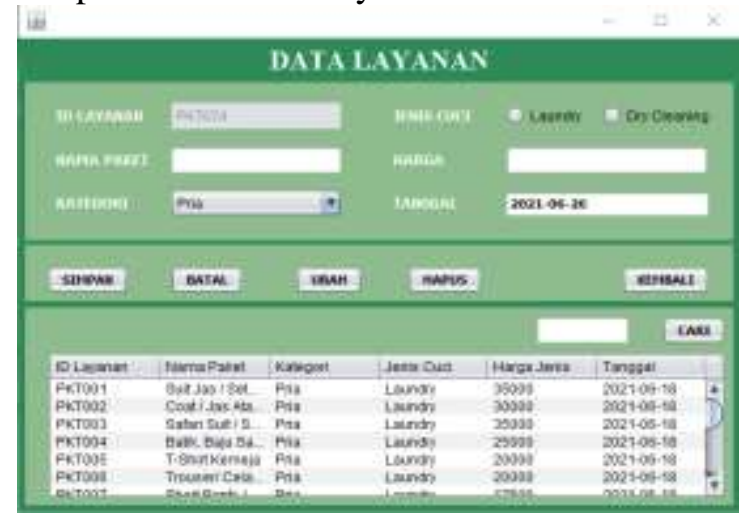

Gambar 8. Tampilan Form Data Layanan

121 | Perancangan Sistem Infromasi Pada CV Arlet Laundry Berbasis Java Netbeans Dan MySQL 
Form data layanan berfungsi untuk menyimpan data layanan pencucian.

Tampilan Form Transaksi Pelanggan Personal

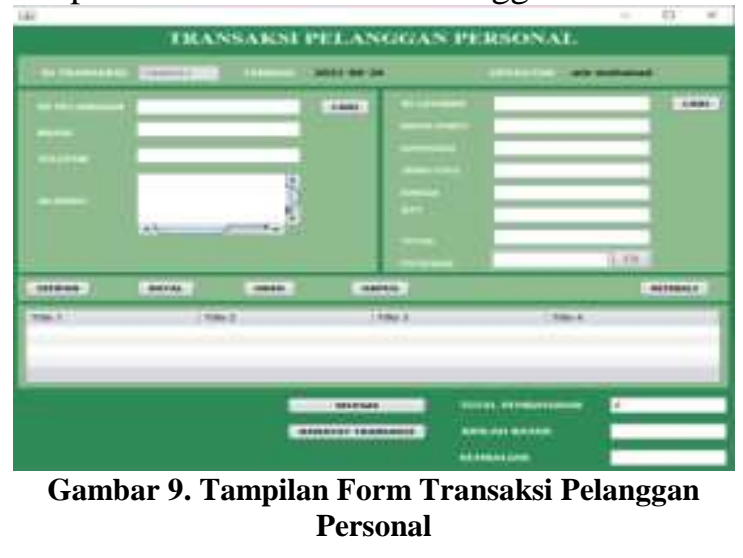

Form transaski pelanggan personal digunakan untuk menyimpan data transaksi pelanggan personal

Tampilan Form Transaksi Pelanggan Corporate

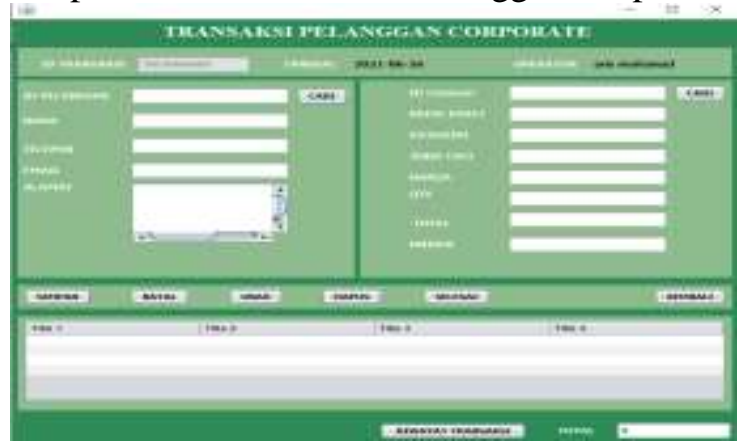

Gambar 10. Tampilan Form Transaksi Pelanggan Corporate

Form transaski pelanggan Corporate digunakan untuk menyimpan data transaksi pelanggan Corporate.

Tampilan Form Pengembalian Pelanggan personal

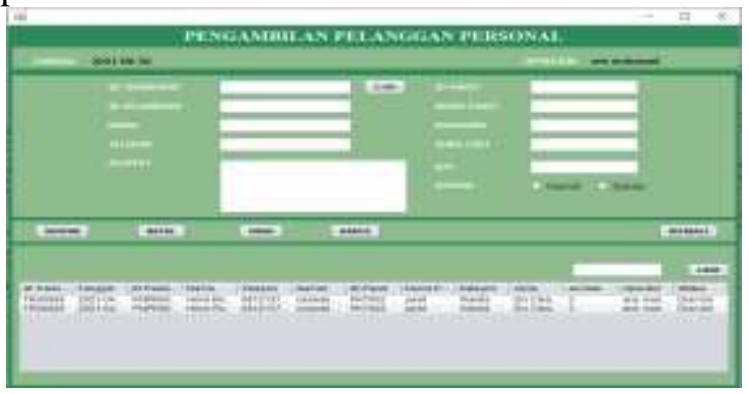

Gambar 11. Tampilan Form pengambilan Pelanggan Personal
Form penggambilan pelanggan pesonal berfungsi menyimpan data pengambilan pelanggan personal.

Invoice Pelanggan Personal

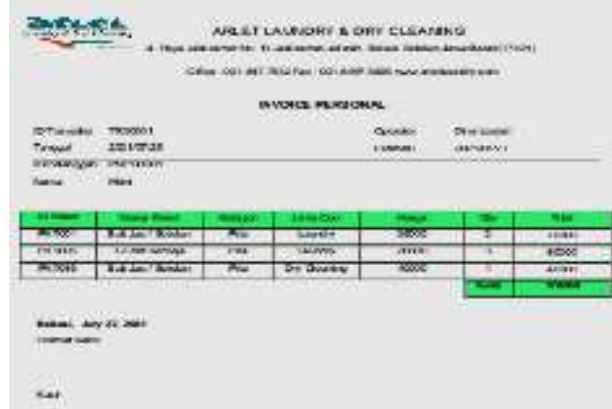

Gambar 12. Tampilan Invoice Pelanggan Personal

Invoice berfungsi sebagai bukti transaksi untuk pelanggan

Invoice Pelanggan Corporate

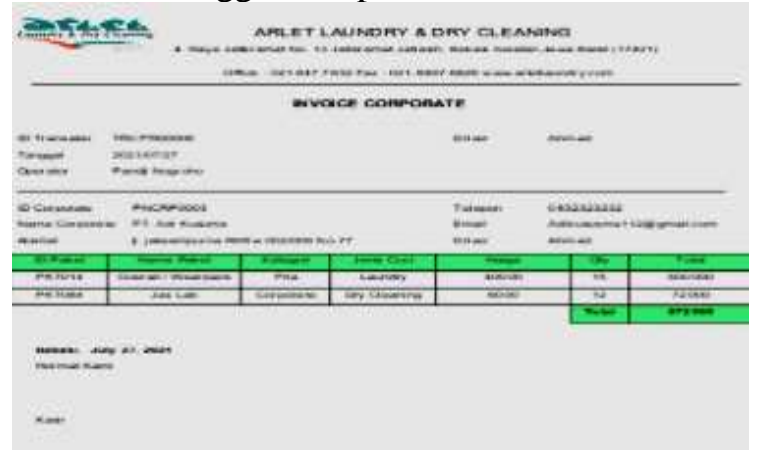

Gambar 13. Tampilan Invoice Pelanggan Corporate

Invoice berfungsi sebagai bukti transaksi untuk pelanggan.

Laporan Data Pelanggan Personal

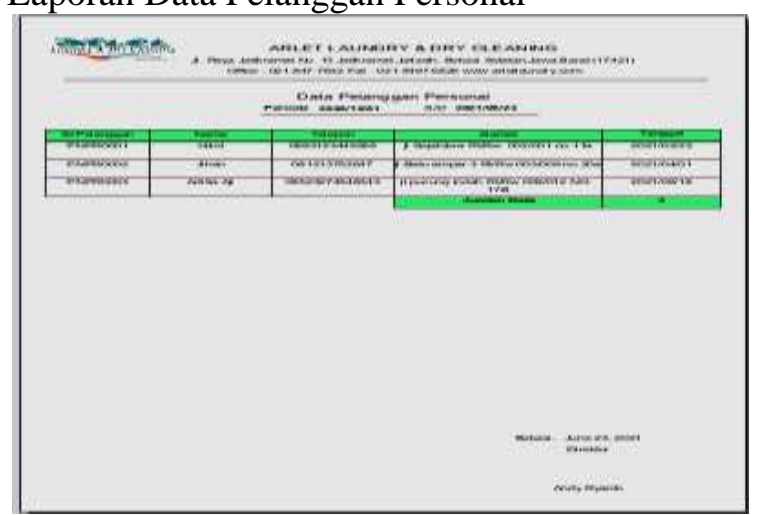

Gambar 14. Laporan data Pelanggan Personal

122 | Perancangan Sistem Infromasi Pada CV Arlet Laundry Berbasis Java Netbeans Dan MySQL 
Laporan data pelanggan personal untuk dilaporkan kepada direktur.

\section{Laporan Data Pelanggan Corporate}

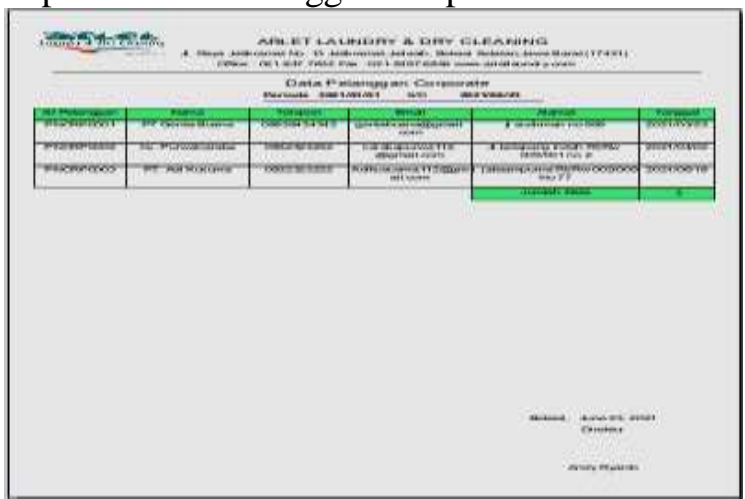

Gambar 15. Laporan data Transaksi Pelanggan Personal

Laporan data pelanggan corporate untuk dilaporkan kepada direktur.

\section{Laporan Data Transaksi Pelanggan Personal}

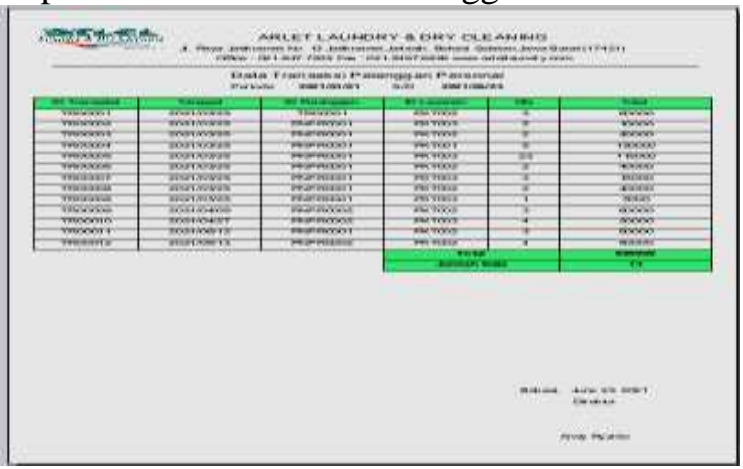

Gambar 16. Laporan Data Transaksi Pelanggan Personal

Laporan data transaksi pelanggan personal akan dilaporkan kepada direktur

\section{Laporan Data Transaksi Pelanggan Corporate}

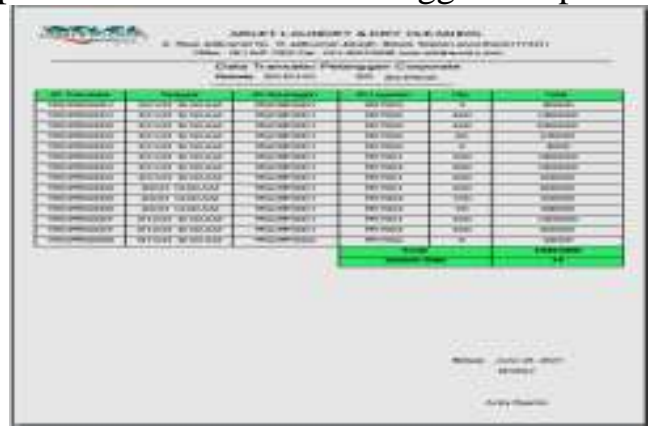

Gambar 17. Laporan Data Transaksi Pelanggan Corporate
Laporan data transaksi pelanggan corporate akan dilaporkan kepada direktur

\section{Laporan Data Pengambilan Pelanggan Personal}

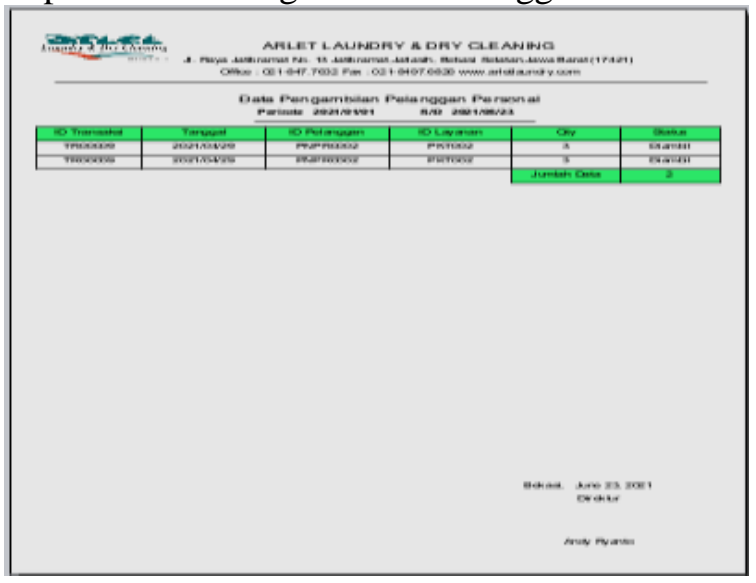

Gambar 18. Laporan Data Pengambilan Pelanggan Personal

Laporan data pengambilan pelanggan personal akan dilaporkan kepada direktur.

\section{Laporan Data Layanan}

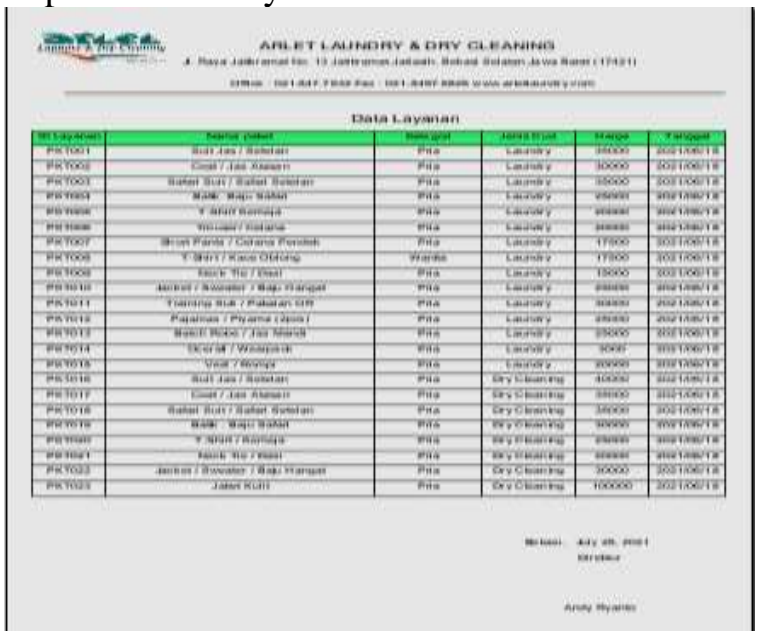

Gambar 19. Laporan Data Layanan

Laporan data layanan akan dilaporkan kepada direktur dan dapat diberikan kepada pelanggan

\section{SIMPULAN DAN SARAN}

Setelah melakukan penelitan pada sistem informasi pada CV Arlet Laundry, maka dihasilkan sebuah program aplikasi yang merupakan bentuk dari perbaikan sistem informasi tersebut yang selama ini masih dilakukan secara manual menjadi berbasis komputer. Pengolahan data data layanan, data

123 | Perancangan Sistem Infromasi Pada CV Arlet Laundry Berbasis Java Netbeans Dan MySQL 
pelanggan, data transaksi, dan data pengambilan yang berbasis komputer dengan mengintegrasikan ke database dapat mempermudah pengaksesan dan pencarian data secara efisien. Program aplikasi ini dibuat sesuai dengan kebijakan dan permintaan dari pihak perusahaan CV Arlet Laundry untuk menangani sistem informasi transaksi.

Saran untuk pengembangan aplikasi ini dapat dikembangkan dalam hal design dan database sesuai dengan kebutuhan. Semua karyawan dapat mengelola aplikasi ini dan memeriksa secara berkala agar dapat melakukan sistem pengolahan datanya dengan baik dan sudah harus terdaftar di data user.

\section{DAFTAR PUSTAKA}

A.S, R., \& Shalahuddin, M. (2016). Rekayasa Perangkat Lunak Terstruktur dan Berorientasi Objek. Bandung : Informatika. In Jurnal Pilar Nusa Mandiri (p. 28).

Bin Ladjamudin, A.-B. (2013). Analisis dan Desain Sistem Informasi. Graha ilmu.

Raharjo, B. (2015). Belajar Otodidak MYSQL (Teknik Pembuatan dan Pengelolaan Database. Informatika.

Sugiyono. (2016). Metode Penelitian Kuantitatif, Kualitatif dan $R \& D$. PT Alfabet.

Sutabri, T. (2012). Konsep Sistem Informasi. Jurnal Administrasi Pendidikan UPI, 3(1), 248.

Tata, S. (2012). Konsep Sistem Informasi (I. Nastiti (ed.)). Andi Offset Manajemen.

Westriningsih. (2012). Panduan Aplikatif \& Solusi (PAS) Membangun Aplikasi. Andi. 